\title{
Effects of Hyperaccumulator Straw on Growth and Cadmium Accumulation of Brassica chinensis
}

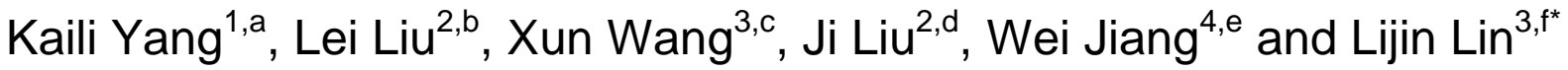 \\ ${ }^{1}$ College of Horticulture, Sichuan Agricultural University, Chengdu, Sichuan, China \\ ${ }^{2}$ Chengdu Academy of Agriculture and Forestry Sciences, Chengdu, Sichuan, China \\ ${ }^{3}$ Institute of Pomology and Olericulture, Sichuan Agricultural University, Chengdu, Sichuan, China \\ ${ }^{4}$ College of Chemistry and Life Science, Chengdu Normal University, Chengdu, Sichuan, China \\ a714284926@qq.com, bskyskyskylover@163.com.cn, '35744023@qq.com, d34905418@qq.com, \\ e1399945180@qq.com, ${ }^{f}$ llj800924@163.com
}

${ }^{*}$ Corresponding author. Kaili Yang, Lei Liu and Xun Wang contributed equally to this work.

Keywords: Brassica chinensis; Hyperaccumulator straw; Cadmium; Growth

Abstract: The pot experiment was conducted to study the effects of applying the hyperaccumulator plants (Bidens pilosa, Youngia erythrocarpa, Solanum photeinocarpum and Galinsoga parviflora) straw into soil on growth and cadmium $(\mathrm{Cd})$ accumulation of Brassica chinensis. Compared with the control, applying hyperaccumulator straw decreased the root biomass, shoot biomass, and photosynthetic pigment contents of $B$. chinensis. The hyperaccumulator straw also decreased the $\mathrm{Cd}$ contents in roots and shoots of $B$. chinensis, and the orders of that were ranked as control $>$ applying $B$. pilosa straw $>$ applying $G$. parviflora straw $>$ applying $Y$. erythrocarpa staw $>$ applying $S$. photeinocarpum straw. Therefore, applying hyperaccumulator straw could decrease the Cd uptake of B. chinensis, and the straw of $S$. photeinocarpum is the best option.

\section{Introduction}

The phytoremediation is a common method for remediation of heavy metal contaminated soil, and can not damage the ecological environment of soil, soil structure and microbial conditions, which uses the roots of plants directly uptakes heavy metals from soil and transfers heavy metals to shoots of plants [1-2]. Some studies show that phytoremediation can be used for cadmium (Cd) contaminated soil [3].

The allelopathy is a direct or indirect, harmful or beneficial effect on plants (including microorganisms), which produces by the process of plant growth or in the process of plant decay [4]. Allelopathy affects soil nutrient availability, soil enzyme activity, microbial population structure and plant growth [5]. Straw application is one of the most important measures to increase soil fertility, which can eliminate the air pollution caused by straw burning, and increases crop yield at the same time [6]. In Cd-contaminated conditions, applying straw of Mazus japonicus, Youngia erythrocarpa, Cardamine hirsuta, and Conyza canadensis to soil significantly increased the biomass, Cd content, and Cd-extraction ability of the Cd-hyperaccumulator Galinsoga parviflora [7-9]. Similarly, straw of C. hirsuta, Nasturtium officinale, and C. Canadensis significantly reduced $\mathrm{Cd}$ accumulation in Capsella bursa-pastoris [10]. Therefore, if the straw could be applied directly to crops and vegetables, it could decrease $\mathrm{Cd}$ absorption and increase the safety of crops for consumption.

Brassica chinensis is a cruciferous vegetable with adaptability, fast growth and high yield [11]. In this study, the Cd-hyperaccumulation plants Bidens pilosa [12], Youngia erythrocarpa [13], Solanum photeinocarpum [14] and Galinsoga parviflora [15] straw were applied into Cd-contaminated soil, and planted the seedlings of $B$. chinensis. The aim of the study was to determine which hyperaccumulator straw could reduce the Cd accumulated in B. chinensis seedlings, and to provide a reference for phytoremediation of soils contaminated with heavy metals. 


\section{Materials and Methods}

Materials. In August 2014, the shoots of B. pilosa, Y. erythrocarpa, S. photeinocarpum and G. parviflora were collected from the Ya'an campus farm of the Sichuan Agricultural University $\left(29^{\circ} 59^{\prime} \mathrm{N}, 102^{\circ} 59^{\prime} \mathrm{E}\right)$, China, from uncontaminated soil areas. The collected shoots of these plants were dried at $80{ }^{\circ} \mathrm{C}$ to constant weight, finely ground and sieved through a 5-mm-mesh nylon sieve. The seeds of $B$. chinensis were purchased in the market.

The inceptisol soil samples (purple soil in the Genetic Soil Classification of China) were collected from the Ya'an campus farm in August 2013. The basic properties of the soil are described in Lin et al. (2014) [7].

Experimental Design. The experiment was conducted in the greenhouse of the Ya'an campus farm from February to June 2015. The soil samples were air dried and passed through a 5-mm sieve. Three kilograms of the air-dried soil was weighed into each polyethylene pot $(18 \mathrm{~cm}$ high and $21 \mathrm{~cm}$ in diameter). $\mathrm{Cd}$ was added to soils as $\mathrm{CdCl}_{2} \cdot 2.5 \mathrm{H}_{2} \mathrm{O}$ at $10 \mathrm{mg} / \mathrm{kg}$ [7] in February 2015. The soil moisture was maintained at $80 \%$ of field capacity for 2 months. The seeds of B. chinensis were sown in farmland of the Ya'an campus farm in March 2015. Six-gram shoots were applied to each pot (2 g shoots per $\mathrm{kg}$ soil), and the soil moisture was maintained at $80 \%$ of field capacity for 1 week. The five experimental treatments in the experiment were control (no straw applied), and straw applied for each of the four plant species (B. pilosa, Y. erythrocarpa, S. photeinocarpum and G. parviflora). Each treatment was replicated three times using a completely randomized design with $10-\mathrm{cm}$ spacing between pots. Four uniform seedlings of B. chinensis (two euphyllas expanded) were transplanted into each pot in April 2015, and the soil moisture content was maintained at $80 \%$ of field capacity from the time the plants were transplanted into the pots until the time the plants were harvested. 2 months later (June 2015), the upper mature leaves of $B$. chinensis were collected to determine the photosynthetic pigment (chlorophyll $a$, chlorophyll $b$, total chlorophyll, and carotenoid) contents [16]. The plants were then gently removed from the soil, and the roots, stems, and leaves were washed with deionized water and dried at $80{ }^{\circ} \mathrm{C}$ to constant weight for dry weight and $\mathrm{Cd}$ content determination [17].

Statistical analyses. Statistical analyses were conducted using SPSS 13.0 statistical software (IBM, Chicago, IL, USA). Data were analyzed by one-way analysis of variance with least significant difference (LSD) at the $\mathrm{p}=0.05$ confidence level. The following calculated were used: translocation factor $(\mathrm{TF})=\mathrm{Cd}$ content in shoots/ $\mathrm{Cd}$ content in roots [18].

\section{Results and Discussion}

Biomass. Under Cd stress, applying the straw of hyperaccumulator straw decreased the root, stem and leaf and shoot biomasses of $B$. chinensis compared with the control (Table 1), indicating that hyperaccumulator straw inhibited the growth of B. chinensis. The biomass of B. chinensis was ranked as: control > applying $S$. photeinocarpum straw > applying B. pilosa straw > applying G. parviflora straw > applying $Y$. erythrocarpa staw. The straw of $Y$. erythrocarpa and G. parviflora improved the root/ shoot ratio of B. chinensis, but the straw of B. pilosa and S. photeinocarpum reduced that (Table $1)$.

Table 1 Biomass of Brassica chinensis

\begin{tabular}{lccccc}
\hline \multicolumn{1}{c}{ Treatments } & $\begin{array}{c}\text { Roots } \\
\text { (g/plant) }\end{array}$ & $\begin{array}{c}\text { Stems } \\
\text { (g/plant) }\end{array}$ & $\begin{array}{c}\text { leaves } \\
(\mathrm{g} / \mathrm{plant})\end{array}$ & $\begin{array}{c}\text { Shoots } \\
\text { (g/plant) }\end{array}$ & $\begin{array}{c}\text { Root/ shoot } \\
\text { ratio }\end{array}$ \\
\hline Control & $0.363 \pm 0.007 \mathrm{a}$ & $0.702 \pm 0.013 \mathrm{a}$ & $1.232 \pm 0.018 \mathrm{a}$ & $1.934 \pm 0.031 \mathrm{a}$ & 0.188 \\
B. pilosa & $0.270 \pm 0.007 \mathrm{c}$ & $0.544 \pm 0.008 \mathrm{c}$ & $0.926 \pm 0.013 \mathrm{~b}$ & $1.470 \pm 0.021 \mathrm{c}$ & 0.184 \\
Y. erythrocarpa & $0.257 \pm 0.004 \mathrm{c}$ & $0.357 \pm 0.004 \mathrm{e}$ & $0.838 \pm 0.011 \mathrm{c}$ & $1.195 \pm 0.016 \mathrm{e}$ & 0.215 \\
S. photeinocarpum & $0.292 \pm 0.006 \mathrm{~b}$ & $0.676 \pm 0.006 \mathrm{~b}$ & $0.969 \pm 0.016 \mathrm{~b}$ & $1.645 \pm 0.021 \mathrm{~b}$ & 0.178 \\
G. parviflora & $0.268 \pm 0.004 \mathrm{c}$ & $0.509 \pm 0.007 \mathrm{~d}$ & $0.853 \pm 0.024 \mathrm{c}$ & $1.362 \pm 0.031 \mathrm{~d}$ & 0.197 \\
\hline
\end{tabular}


Photosynthetic Pigment Content. When applying the straw of hyperaccumulaor into soil, the straw of B. pilosa, Y. erythrocarpa and G. parviflora significantly decreased the chlorophyll $a$ and total chlorophyll contents in B. chinensis compared with the control (Table 2). There were no significant differences of chlorophyll $a$ and total chlorophyll contents in B. chinensis by the straw of $S$. photeinocarpum. The straw of $Y$. erythrocarpa and $G$. parviflora significantly decreased the chlorophyll $b$ contents in $B$. chinensis compared with the control, but there were no no significant differences by the straw of B. pilosa and $S$. photeinocarpum. All of four hyperaccumulator straw significantly decreased the carotenoid content in B. chinensis compared with the control. The straw of B. pilosa, Y. erythrocarpa and S. photeinocarpum reduced the chlorophyll a/b of $B$. chinensis, and the straw of $G$. parviflora improved that (Table 2). The order of chlorophyll a/b was applying $G$. parviflora straw > control > applying B. pilosa straw > applying $Y$. erythrocarpa staw $>$ applying $S$. photeinocarpum straw.

Table 2 Photosynthetic pigment content in Brassica chinensis

\begin{tabular}{lccccc}
\hline \multicolumn{1}{c}{ Treatments } & $\begin{array}{c}\text { Chlorophyll } a \\
(\mathrm{mg} / \mathrm{g})\end{array}$ & $\begin{array}{c}\text { Chlorophyll } b \\
(\mathrm{mg} / \mathrm{g})\end{array}$ & $\begin{array}{c}\text { Total chlorophyll } \\
(\mathrm{mg} / \mathrm{g})\end{array}$ & $\begin{array}{c}\text { Chlorophyll } \\
\mathrm{a} / \mathrm{b}\end{array}$ & $\begin{array}{c}\text { Carotenoid } \\
(\mathrm{mg} / \mathrm{g})\end{array}$ \\
\hline Control & $0.643 \pm 0.007 \mathrm{a}$ & $0.122 \pm 0.008 \mathrm{ab}$ & $0.765 \pm 0.015 \mathrm{a}$ & 5.265 & $0.236 \pm 0.004 \mathrm{a}$ \\
B. pilosa & $0.535 \pm 0.018 \mathrm{~b}$ & $0.108 \pm 0.004 \mathrm{bc}$ & $0.643 \pm 0.023 \mathrm{~b}$ & 4.977 & $0.205 \pm 0.007 \mathrm{c}$ \\
Y. erythrocarpa & $0.504 \pm 0.007 \mathrm{~b}$ & $0.102 \pm 0.004 \mathrm{c}$ & $0.606 \pm 0.003 \mathrm{~b}$ & 4.931 & $0.181 \pm 0.003 \mathrm{~d}$ \\
S. photeinocarpum & $0.624 \pm 0.011 \mathrm{a}$ & $0.133 \pm 0.008 \mathrm{a}$ & $0.757 \pm 0.003 \mathrm{a}$ & 4.699 & $0.219 \pm 0.003 \mathrm{~b}$ \\
G. parviflora & $0.532 \pm 0.024 \mathrm{~b}$ & $0.100 \pm 0.006 \mathrm{c}$ & $0.632 \pm 0.030 \mathrm{~b}$ & 5.306 & $0.197 \pm 0.006 \mathrm{c}$ \\
\hline
\end{tabular}

Cadmium Content. The hyperaccumulator straw decreased the $\mathrm{Cd}$ contents in roots, stems, leaves and shoots of B. chinensis compared with the control (Table 3). The Cd contents in roots, stems, leaves and shoots of $B$. chinensis were ranked as control $>$ applying $B$. pilosa straw $>$ applying $G$. parviflora straw $>$ applying $Y$. erythrocarpa staw $>$ applying $S$. photeinocarpum straw. The $B$. pilosa straw decreased the $\mathrm{Cd}$ contents in roots and shoots of B. chinensis by $6.81 \%(p>0.05)$ and $5.08 \%$ $(p>0.05)$ respectively compared with the control, $Y$. erythrocarpa straw decreased by $25.07 \%$ ( $p<$ $0.05)$ and $20.81 \%(p<0.05)$ respectively compared with the control, S. photeinocarpum straw decreased by $37.88 \%(p<0.05)$ and $35.03 \%(p<0.05)$ respectively compared with the control, and $G$. parviflora straw decreased by $14.99 \%(p<0.05)$ and $14.21 \%(p<0.05)$ respectively compared with the control. The hyperaccumulator straw improved the TF of $B$. chinensis, and the order of TF was applying $Y$. erythrocarpa staw $>$ applying $S$. photeinocarpum straw $>$ applying $B$. pilosa straw $>$ applying G. parviflora straw > control (Table 3).

Table 3 Cadmium content in Brassica chinensis

\begin{tabular}{llcccc}
\hline \multicolumn{1}{c}{ Treatments } & \multicolumn{1}{c}{$\begin{array}{c}\text { Roots } \\
(\mathrm{mg} / \mathrm{kg})\end{array}$} & $\begin{array}{c}\text { Stems } \\
(\mathrm{mg} / \mathrm{kg})\end{array}$ & $\begin{array}{c}\text { Leaves } \\
(\mathrm{mg} / \mathrm{kg})\end{array}$ & $\begin{array}{c}\text { Shoots } \\
(\mathrm{mg} / \mathrm{kg})\end{array}$ & TF \\
\hline Control & $3.67 \pm 0.13 \mathrm{a}$ & $0.44 \pm 0.010 \mathrm{a}$ & $2.84 \pm 0.13 \mathrm{a}$ & $1.97 \pm 0.09 \mathrm{a}$ & 0.537 \\
B. pilosa & $3.42 \pm 0.16 \mathrm{ab}$ & $0.41 \pm 0.011 \mathrm{~b}$ & $2.72 \pm 0.07 \mathrm{a}$ & $1.87 \pm 0.05 \mathrm{a}$ & 0.547 \\
Y. erythrocarpa & $2.75 \pm 0.18 \mathrm{c}$ & $0.23 \pm 0.006 \mathrm{~d}$ & $2.13 \pm 0.04 \mathrm{c}$ & $1.56 \pm 0.03 \mathrm{~b}$ & 0.567 \\
S. photeinocarpum & $2.28 \pm 0.11 \mathrm{~d}$ & $0.19 \pm 0.008 \mathrm{e}$ & $2.04 \pm 0.05 \mathrm{c}$ & $1.28 \pm 0.03 \mathrm{c}$ & 0.561 \\
G. parviflora & $3.12 \pm 0.14 \mathrm{bc}$ & $0.36 \pm 0.007 \mathrm{c}$ & $2.48 \pm 0.10 \mathrm{~b}$ & $1.69 \pm 0.06 \mathrm{~b}$ & 0.542 \\
\hline
\end{tabular}

\section{Conclusions}

Under Cd stress, applying hyperaccumulator plants (B. pilosa, Y. erythrocarpa, S. photeinocarpum and $G$. parviflora) straw decreased the root biomass, shoot biomass, and photosynthetic pigment contents of $B$. chinensis. The hyperaccumulator straw also decreased the $\mathrm{Cd}$ contents in roots and shoots of B. chinensis, and the orders of that were ranked as control $>$ applying B. pilosa straw $>$ 
applying G. parviflora straw $>$ applying $Y$. erythrocarpa staw $>$ applying $S$. photeinocarpum straw. Therefore, applying hyperaccumulator straw could decrease the $\mathrm{Cd}$ uptake of $B$. chinensis, and the straw of $S$. photeinocarpum is the best option.

\section{References}

[1] A.P.G.C. Marques, A.O.S.S. Rangel and P.M.L. Castro: Critical Reviews in Environmental Science and Technology Vol. 39, (2009), p. 622.

[2] S.D. Gham, W.R. Berti and J.W. Huang: Trends in Biotechnology Vol. 13, (1995), p. 393.

[3] D. Su and H. Huang: China Environmental Science Vol. 22 (2002), p. 48.

[4] H.P. Bais, R. Vepachedu, S. Gilroy, R.M. Callaway and J.M. Vivanco: Science Vol. 301, (2003), p. 1377.

[5] J.L. Hierro, R.M. Callaway, J.L. Hierro and R. M. Callaway: Plant and Soil Vol. 256, (2003), p. 29.

[6] F. Lu, X. Wang, B. Han, Z. Ouyang, X. Duan, H. Zheng and H. Miao Global Change Biology Vol. 15, (2008), p. 281.

[7] L. Lin, M. Liao, Y. Ren, L. Luo, X. Zhang, D. Yang and J. He: PLoS ONE Vol. 9, (2014), p. e114957.

[8] J. Wang, C. Liu, X. Zhang, L. Lin, M. Liao, X. Lv, H. Xia and D. Liang: Environmental Progress \& Sustainable Energy Vol. 35, (2016), p. 618.

[9] F.Y. Tang, L.J. Lin, J.Q. Liao, M.A. Liao, J. He, D. Yang and X. Zhang: Acta Agriculturae Boreali-Sinica Vol. 30, (2015), p. 213.

[10]L. Lin, D. Yang, F. Tang, L. Luo, M. Liao and L.Yuan: Chinese Journal of Soil Science Vol. 46, (2015), p. 483.

[11]Y. Chen, T.Q. Li, X.E. Yang and Y.F. Jin: Chinese Journal of Applied Ecology Vol. 20, (2009), p. 736.

[12]Y. Sun, Q. Zhou, L. Wang and W. Liu: Journal of Hazardous Materials Vol. 161, (2009), p. 808.

[13]L. Lin, B. Ning, M. Liao, Y. Ren, Z. Wang, Y. Liu, J. Cheng and L. Luo: Environmental Monitoring and Assessment Vol. 187, (2015), p. 4205.

[14]X.F. Zhang, H.P. Xia, Z.A. Li, P. Zhuang and B. Gao: Journal of Hazardous Materials Vol. 189, (2011), p. 414.

[15]L.J. Lin, Q. Jin, Y.J. Liu, B. Ning, M.A. Liao and L. Luo: Environmental Toxicology and Chemistry Vol. 33, (2014), p. 2422.

[16]Z.B. Hao, J. Chang and Z. Xu: Plant Physiology Experiment (Harbin Institute of Technology Press, China 2004).

[17] S.D. Bao: Agrochemical Soil Analysis (3rd edition, China Agriculture Press, Beijing, China 2000).

[18]F. Rastmanesh, F. Moore and B. Keshavarzi: Bulletin of Environmental Contamination and Toxicology Vol. 85, (2010), p. 515. 